Отримано: 12 травня 2018 р.

Прорецеензовано: 19 травня 2018 р.

Прийнято до друку: 24 травня 2018 р.

e-mail: ryszard.pukala@interia.pl
Ришард П. Аналіз результатів здійснення пруденційного нагляду за діяльністю фінансових установ. Наукові записки Наиіонального університету «Острозька академія». Серія «Економіка» : науковий журнал. Острог : Вид-во НаУОА, червень 2018. № 9(37). С. 162-167.

\footnotetext{
DOI: $10.25264 / 2311-5149-2018-9(37)-162-167$
}

УДК 336.1 .07

JEL-класифікація: $G 18$

Ришард Пукала,

кандидат економічних наук, $P h D$,

проректор Державної вищої техніко-економічної иколи ім. Б. Маркевича в Ярославі

\title{
АНАЛІЗ РЕЗУЛЬТАТІВ ЗДІЙСНЕННЯ ПРУДЕНЦІЙНОГО НАГЛЯДУ ЗА ДІЯЛЬНІСТЮ ФІНАНСОВИХ УСТАНОВ
}

У статті розглянуто результати впровадження для управління ризиками фінансових установ пруденційного нагляду, виконано аналіз звітних даних діяльності фінансових установ за видами для нагляду (страхові компанії, кредитні спілки ломбарди, суб'єкти недержавного пенсійного забезпечення та ін.) в динаміиі з 2014 по 2017 рік. Встановлено зміни в індикативних показниках застосування заходів впливу пруденційного нагляду щодо ненадання звітності в терміни, визначені законодавством, за недотримання нормативів, невиконання раніше застосованих заходів впливу.

Ключові слова: пруденційний нагляд, фінансова установа, звітні дані, державне регулювання.

Рышард Пукала,

кандидат экономических наук, $P h D$,

проректор Государственной высшей технико-экономической иколы им. Б.Маркевича в Ярославе

\section{АНАЛИЗ РЕЗУЛЬТАТОВ ОСУЩЕСТВЛЕНИЯ ПРУДЕНЦИАЛЬНОГО НАДЗОРА ЗА ДЕЯТЕЛЬНОСТЬЮ ФИНАНСОВЫХ УЧРЕЖДЕНИЙ}

В статье рассмотрены результаты внедрения для управления рисками финансовых учреждений пруденциального надзора, выполнен анализ отчетных данных деятельности финансовых учреждений по видам для надзора (страховые компании, кредитные союзы, ломбарды, субъекты негосударственного пенсионного обеспечения и др..) в динамике с 2014 по 2017 год. Установлено изменения в индикативных показателях применения мер влияния пруденцилльного надзора относительно непредставления отчетности в сроки, установленные законодательством, за несоблюдение нормативов, невыполнение ранее примененных мер влияния.

Ключевые слова: пруденцииальный надзор, финансовое учреждение, отчетные данные, государственное регулирование.

Pukala Ryszard,

Ph. D. in Economics,

Vice-rector of the B.Markiewicz State Higher School of Technology and Economics in Jaroslaw

\section{ANALYSIS OF PRUDENTIAL SUPERVISION PERFORMANCE RESULTS IN TERMS OF INSTITUTION'S FINANCIAL ACTIVITY}

The article deals with the results of prudential supervision implementation in terms of financial institutions risk management, the financial institution's activities reporting data by supervision types (insurance companies, credit unions pawn shops, subjects of non-state pension provision, etc.) in the dynamics from 2014 to 2017 was analyzed. The authors defined the changes in the indicators of influence measures application in terms of prudential supervision on non-reporting in the terms defined by the legislation, for failure to comply with standards, and failure to comply with previously applied influence measures.

Key words: prudential supervision, financial institution, reporting data, state regulation.

Постановка проблеми. Для забезпечення можливості розвитку основних принципів і норм державного регулювання необхідне формування нових стандартів, побудованих на публічності та відкритості, що відповідає цілям демократії в СС. Громадяни будь-якої європейської країни мають право на інформацію й участь в управлінні справами державного рівня через аналіз фінансової звітності й іншої інформації, яка надає можливість впливати на зміни. Саме її врахування надасть змогу розвивати комунікативну складову між владою та суспільством, а також приймати зважені й ефективні рішення. 
Зобов’язання України в межах адаптації до європейського законодавства визначають напрями імплементації Директиви 2013/36/ЄС Європейського Парламенту та Ради від 26.06.2013 та Регламенту Європейського Парламенту та Ради (СС) 575/2013 від 26.06.2013 про доступ, пруденційний нагляд, вимоги до діяльності кредитних установ та інвестиційних компаній.

Із цією метою в Україні прийнято Концепцію запровадження пруденційного нагляду за небанківськими фінансовими установами [3].

Пруденційний нагляд - це одна зі складових системи нагляду держави, яка базується на регулярному проведенні оцінки фінансового стану підприємств, зокрема, фінансових установ. Нагляд здійснюють спеціальні органи, які відповідають за державне регулювання ринків фінансових послуг. Заходи нагляду полягають в оцінюванні результатів діяльності установ, а також аналізі рівня дотримання організацією норм і нормативів, які встановлені органом регулювання. В Україні за пруденційний нагляд фінансових установ відповідає Національна комісія, що здійснює державне регулювання у сфері ринків фінансових послуг (Нацкомфінпослуг України) [5], у Польщі - Комісія фінансового нагляду (КФН) [16]. Основною місію Нацкомфінпослуг України $є$ забезпечення необхідних умов для ефективної роботи фінансових установ ринку фінансових послуг. Орган забезпечує захист прав споживачів фінансових послуг та інтеграцію у європейський фінансовий простір, забезпечуючи фінансову безпеку держави. Ця місія співпадає з ціліями діяльність Європейської системи фінансового нагляду, завданням якої є підтримка стабільності фінансової системи та захист споживачів фінансових послуг ЄС.

Для гарантії споживачам в отриманні достовірної інформації та забезпечення прозорості діяльності орган регулювання щорічно складає публічні звіти про свою діяльність [4; 7; 8]. Оприлюднені звіти містять інформацію про результати проведення пруденційного нагляду.

Аналіз останніх досліджень і публікацій. Питаннями аналізу результатів пруденційного нагляду органів регулювання займаються поодинокі дослідники як в Україні [1,2], так і Польщі [13,14,15], тому проведення такого аналізу є актуальним для формування пропозицій і стратегій щодо вдосконалення процесів пруденційного нагляду.

Мета дослідження - порівняльний аналіз результатів здійснення пруденційного нагляду за діяльністю фінансових установ в Україні із урахуванням досвіду Польщі.

Завдання дослідження - проаналізувати в динаміці результати пруденційного нагляду за фінансовими установами в розрізі ринків фінансових послуг за даними публічних звітів регулятора, порівняти індикативні показники складених актів відповідно до кількості фінансових установ за 2016-2017 рр. для визначення напрямів удосконалення пруденційного нагляду з урахуванням досвіду ЄС.

Виклад основного матеріалу. Законом України «Про фінансові послуги та державне регулювання ринків фінансових послуг» визначено основні напрями пруденційного нагляду Нацкомфінпослуг [6]. Спрямування нагляду містить дотримання фінансовими установами встановлених нормативів і критеріїв щодо якості активів і ризиковості операцій, ліквідності, прибутковості, капіталу та платоспроможності, якості систем управління й управлінського персоналу, додержання норм надання фінансових послуг.

Нацкомфінпослуг в Україні, як і КФН у Польщі, самостійно встановлює правила підготовки та надання даних про діяльність фінансових установ згідно з законодавчо встановленими напрямами здійснення пруденційного нагляду. Регулятор незалежно визначає закономірність і доречність його проведення.

За даними, які отримує встановлений орган державного регулювання в результаті перевірки відповідності показників пруденційним нормативам, складають і оприлюднюють Публічний звіт як в Україні [9; $10 ; 11 ; 12]$, так і Польщі $[7 ; 8]$. Результати пруденційного нагляду здебільшого публікують в окремому розділі звіту. Далі здійснено аналіз оприлюднених результатів пруденійного нагляду в Україні в динаміці. За 2014 рік фінансовими установами до Нацкомфінпослуг подано 10764 звітних даних, за результатами аналізу яких складено 734 акти про правопорушення [9], тобто 0,068 на одиниці звітності, 3 них 40\% - за ненадання звітності в терміни, визначені законодавством. Серед порушників визначено кредитні спілки, ломбарди, юридичні особи, які не $\epsilon$ фінансовими установами, але мають право надавати фінансові послуги, а значить повинні звітувати.

Щодо недотримання нормативів (17,7\%), то тут відзначились страхові компанії, кредитні спілки та ломбарди. Негативним у системі нагляду є те, що фінансові установи не реагують на заходи впливу і не виконують приписів, що склало $20 \%$ серед складених актів про правопорушення.

Результати пруденційного нагляду за 2014 рік подано в таблиці 1.

Як видно з таблиці 1, найбільшим сегментом ринку за кількістю поданих звітних даних 2014 року був страховий ринок та узагальнений ринок небанківських фінансових установ разом із ломбардами. Проте кількість складених актів правопорушень до кількості поданих звітних даних на ринку кредитних установ $є$ найвищою, що потребує додаткових інструментів нагляду. 
Інформація про результати пруденційного нагляду за сегментами ринку фінансових послуг України за 2014 рік

\begin{tabular}{|l|c|c|}
\hline \multicolumn{1}{|c|}{$\begin{array}{c}\text { Сегменти ринку } \\
\text { фінансових послуг }\end{array}$} & $\begin{array}{c}\text { Питома вага поданих звітних } \\
\text { даних за сегментами ринку } \\
\text { фінансових послуг, \% }\end{array}$ & $\begin{array}{c}\text { Відношення кількості складених актів порушення за } \\
\text { результатами аналізу звітних даних до кількості по- } \\
\text { даних звітних даних за кожним сегментом ринку, \% }\end{array}$ \\
\hline Страховий ринок & 22,75 & 9,2 \\
\hline Ринок кредитних установ & 15,66 & 16,2 \\
\hline $\begin{array}{l}\text { Ринок небанківських } \\
\text { фінансових установ і } \\
\text { ломбардів }\end{array}$ & 59,1 & 3,3 \\
\hline $\begin{array}{l}\text { Ринок недержавного пен- } \\
\text { сійного забезпечення }\end{array}$ & 2,49 & 8,25 \\
\hline Усього & 100,0 & У середньому 6,8 \\
\hline
\end{tabular}

За отриманими результатами прийнято регулятором ряд рішень щодо впливу на фінансові установи, серед яких найбільша кількість стосувалася страхових компаній, кредитних спілок і ломбардів, що загалом відповідає проаналізованій структурі правопорушень по ринках фінансових послуг.

За результатами пруденційного нагляду було анулювання ліцензій, виключення з реєстру фінансових установ, накладання штрафних санкцій.

2015 року регулятором продовжено заходи пруденційного нагляду. Фінансовими установами до Нацкомфінпослуг подано на 5,5\% звітних даних більше, а за результатами аналізу складено на $35,4 \%$ більше актів про правопорушення щодо 2014 року [10]. За структурою 2014 року зміни щодо порушень за ненадання звітності в терміни, визначені законодавством зменшилися на 1 п.п., проте до фінансових установ, які потрапили в зону впливу, з'явились страхові брокери, компанії публічного права, що свідчить про уразливість будь-яких фінансових установ щодо дотримання норм права. Негативним $є$ те, що суттєво збільшилася кількість правопорушень за недотримання нормативів (36,1\% до загальної кількості), а позитивним те, що лише 8\% фінансових установ, порівняно з 20\% 2014 р. не виконали раніше застосовані заходи впливу. Це стосується всіх ринків.

Результати пруденційного нагляду за 2015 рік подано в таблиці 2.

Таблиия 2

Інформація про результати пруденційного нагляду за сегментами ринку фінансових послуг України за 2015 рік

\begin{tabular}{|l|c|c|}
\hline \multicolumn{1}{|c|}{$\begin{array}{c}\text { Сегменти ринку } \\
\text { фінансових послуг }\end{array}$} & $\begin{array}{c}\text { Питома вага поданих звітних } \\
\text { даних за сегментами ринку } \\
\text { фінансових послуг, \% }\end{array}$ & $\begin{array}{c}\text { Відношення кількості складених актів порушення за } \\
\text { результатами аналізу звітних даних до кількості по- } \\
\text { даних звітних даних за кожним сегментом ринку, \% }\end{array}$ \\
\hline Страховий ринок & 21,5 & 10,75 \\
\hline Ринок кредитних установ & 18,5 & 17,6 \\
\hline $\begin{array}{l}\text { Ринок небанківських } \\
\text { фінансових установ і } \\
\text { ломбардів }\end{array}$ & 56,3 & 5,4 \\
\hline $\begin{array}{l}\text { Ринок недержавного пен- } \\
\text { сійного забезпечення }\end{array}$ & 3,7 & 3,8 \\
\hline Усього & 100,0 & У середньому 8,76 \\
\hline
\end{tabular}

Як видно з таблиці 2, 2015 року щодо 2014 року відношення кількості складених актів порушення за результатами аналізу звітних даних до кількості поданих звітних даних за кожним сегментом ринку в середньому збільшилося, структура цього показника майже не змінилася, крім ринку недержавного пенсійного забезпечення, де показник зменшився майже на 5 пп. Щодо питомої ваги поданих звітних даних за ринками фінансових послуг, iї структура також майже не змінилася, найбільша питома вага залишилася за тими ж ринками, що і 2014 року.

Після отримання таких даних пруденційного нагляду, регулятором прийнято ряд рішень, серед яких анулювання ліцензій, штрафи, виключення з Державного реєстру фінансових установ. 2015 року зросла кількість складених актів щодо порушень, що свідчить про недотримання фінансовими установами нормативів і правил, які установлені Нацкомфінпослуг. Незважаючи на прийняті міри, спрямовані на зменшення правопорушень, фінансові установи продовжують їх не дотримуватися. Така ситуація $\epsilon$ негативною і свідчить про нехтування компаніями вимог законодавства та можливе їх неефективне функціонування. 
За 2016 рік фінансовими установами до Нацкомфінпослуг подано ще більше звітних даних, за результатами аналізу яких складено 2078 актів про правопорушення [11], що на 18,3\% більше , ніж 2015 року. За структурою $61,6 \%$ - за ненадання звітності в терміни, визначені законодавством. До складу ринків фінансових послуг увійшли страхові компанії, страхові брокери, кредитні спілки, фінансові компанії, ломбарди, а також адміністратори недержавного пенсійного фонду, управителі ФОН і ФФБ. Цей показник суттєво збільшився щодо 2014 і 2015 років. Із приводу недотримання нормативів серед загальної кількості порушень складають 19,2\%. Збільшилися 2015 року невиконання заходів впливу (9,6\%), які допустили страхові компанії, кредитні спілки, ломбарди, фінансові компанії.

Результати пруденційного нагляду за 2016 рік подано в таблиці 3.

Інформація про результати пруденційного нагляду

Таблиця 3

за сегментами ринку фінансових послуг України за 2016 рік

\begin{tabular}{|l|c|c|}
\hline \multicolumn{1}{|c|}{$\begin{array}{c}\text { Сегменти ринку } \\
\text { фінансових послуг }\end{array}$} & $\begin{array}{c}\text { Питома вага поданих звіт- } \\
\text { них даних за сегментами } \\
\text { ринку фінансвих послуг, \% }\end{array}$ & $\begin{array}{c}\text { Відношення кількості складених актів } \\
\text { порушеняя за результатами аналізу звітних } \\
\text { даних до кількості поданих звітних даних } \\
\text { за кожним сегмнтом ринку, \% }\end{array}$ \\
\hline Страховий ринок & 19,44 & 12,76 \\
\hline Кредитний ринок & 16,9 & 41,16 \\
\hline $\begin{array}{l}\text { Ринок небанківських фінансо- } \\
\text { вих установ }\end{array}$ & 57,24 & 13,34 \\
\hline $\begin{array}{l}\text { Ринок недержавного пенсій- } \\
\text { ного забезпечення, управите- } \\
\text { лів ФОН і ФФБ }\end{array}$ & 6,42 & 3,76 \\
\hline Усього & 100,0 & У середньому 17,3 \\
\hline
\end{tabular}

Як видно з таблиці 3, структура питомої ваги поданих звітних даних за сегментами ринку фінансових послуг майже не змінилася, додалися додаткові відомості щодо управителів ФОН і ФФБ. Щодо складених актів порушення за результатами аналізу звітних даних, то їх кількість збільшилась. Особливо відчутно це стосується кредитного ринку, де відсоток порушень складає більше $40 \%$, що є загрозливою цифрою. Середня величина також виросла майже у два рази відповідно до 2015 року і у 2,5 рази щодо 2014 року. Це свідчить про збільшення небезпеки функціонування ринку фінансових послуг.

За результатами аналізу звітних даних 2016 року Нацкомфінпослуг здійснено заходи пруденційного нагляду до фінансових установ застосовано 1937 заходів впливу [11], що трохи менше, ніж 2015 року, серед яких 19,88\% стосуються розпоряджень про усунення порушень. Регулятором виключено з Державного реєстру фінансові установи, накладено штрафні санкції.

У публічному звіті про діяльність Нацкомфінпослуг за 2017 рік [12] за результатами розгляду справ про правопорушення за напрямом пруденційного нагляду у 2017 році застосовано 1177 заходів впливу (що на 39,2\% менше, ніж 2016 року). За всіма ринками фінансових послуг відбулося зменшення заходів впливу пруденційного нагляду, крім суб'єктів недержавного пенсійного забезпечення, де їх стало у 3,8 рази більше, ніж 2016 року.

Особливість пруденційного регулювання 2017 року відзначалась тим, що в разі вдосконалення надання Нацкомфінпослуг адміністративних послуг має відбуватися їх змістовне наповнення, виходячи з цілей пруденційного нагляду та найкращої світової практики.

Пруденційний нагляд забезпечується в Нацкомфінпослуг на постійній основі, відбувається щоквартальний аналіз звітних даних суб'єктів нагляду на предмет оцінки фінансового стану фінансової установи, дотримання ними вимог до платоспроможності й інших обов'язкових пруденційних нормативів.

2017 року пріоритетними напрямами здійснення пруденційного нагляду, наприклад, за діяльністю страхових компаній визначено контроль за дотриманням вимог до управління ризиками, розкриття інформації та підвищення відповідальності фінансових установ за порушення встановлених вимог. Додаткові вимоги визначені з метою пруденційного нагляду щодо стрес-тестування страховиків. Пруденційний нагляд у системі недержавного пенсійного забезпечення базується на контролі відповідно до вимог чинного законодавства за веденням бухгалтерського обліку, складанням і поданням звітності з недержавного пенсійного забезпечення адміністраторів НПФ. Пруденційний нагляд за діяльністю фінансових компаній - управителів ФФБ і ФОН базується на дотриманні ліцензіатом протягом терміну дії ліцензії на провадження господарської діяльності з надання фінансових послуг.

2017 році до Нацкомфінпослуг прийнято й опрацьовано, порівняно з 2016 роком зменшену загальну кількість поданих пакетів звітних документів на 3,9\%, що пов'язано із зменшенням кількості фінансових установ. За результатами здійснення пруденційного нагляду, зокрема за недотримання встановлених нормативів, ненадання, несвоєчасне надання або надання недостовірної інформації, невиконання раніше 
застосованих заходів впливу, протягом звітного року складено на 39,6\% менше актів [12], ніж 2016 року у зв'язку з покращенням виконання небанківськими фінансовими установами вимог законодавства 3 питань регулювання ринків небанківських фінансових послуг.

У таблиці 4 наведено індикативні показники складених актів відповідно до кількості фінансових установ за їх видами [12] за 2016-2017 рр.

Індикативні показники кількості складених актів про правопорушення до кількості фінансових установ за видами на ринку фінансових послуг України за 2016-2017 рр.

\begin{tabular}{|l|c|c|c|}
\hline \multirow{2}{*}{ Фінансові установи } & Значення індикативного показника по роках & Tемп змін, \\
\cline { 2 - 4 } & $\mathbf{2 0 1 6}$ & $\mathbf{2 0 1 7}$ & $\begin{array}{c}\mathbf{2 0 1 7 / 2 0 1 6} \\
\mathbf{\%}\end{array}$ \\
\hline Страхові компанії & 0,96 & 0,78 & 81,25 \\
\hline Кредитні спілки & 1,55 & 0,86 & 55,48 \\
\hline Суб'єкти недержавного пенсійного забезпечення & 0,08 & 0,42 & 5,25 рази \\
\hline Фінансові компанії & 0,64 & 0,45 & 70,31 \\
\hline Ломбарди & 0,50 & 0,34 & 68,0 \\
\hline Лізингодавці & 1,33 & 0,69 & 51,88 \\
\hline
\end{tabular}

Як видно з таблиці 4, всі види фінансових установ покращили виконання пруденційних нормативів і правил, крім суб'єктів недержавного пенсійного забезпечення. Враховуючи, що 2017 року Нацкомфінпослуг із метою налагодження системи завчасного звітувати про реалізацію головних ризиків у діяльності установ для страховиків зі страхування життя та страховиків, щодо діяльності яких прибуває певна кількість скарг, уведено щодекадне інформування регулятора про дотримання фінансових нормативів і про істотні операції з активами, подібні рішення і заходи впливу необхідно застосувати і до суб'єктів недержавного пенсійного забезпечення до покращення виконання ними вимог пруденційного нагляду.

Висновки. Отже, аналіз звітів про результати пруденційного нагляду суб'єктів ринку фінансових послуг вказує на те, що певна кількість фінансових установ не дотримується встановлених Нацкомфінпослуг нормативів. Це доводить необхідність удосконалення системи нагляду за діяльністю установ на ринках фінансових послуг. Особливої актуальності для вдосконалення нагляду отримує виконання нормативів щодо своєчасності подання звітних даних, виконання правил прозорості та публічності звітних даних діяльності фінансових установ.

Державний орган регулювання повинен запроваджувати індикатори аналізу річної фінансової звітності фінансових установ, які були б чутливішими до зміни фінансового стану, втрати рівня надійності та ризиковості проведених операцій. Особливу увагу слід приділяти розробці форм і термінів складання звітності, яка б вводила перелік актуалізованих показників для визначення фінансової стійкості, надійності фінансових установ і виконання пруденційних нормативів.

Ефективний нагляд за ринком фінансових послуг у Польщі, який здійснює орган регулювання, призначений для досягнення мети щодо захисту прав споживачів, сприяє стабілізації фінансового сектору й обмеженню виникнення системного ризику, що є позитивним досвідом для України.

\section{Література:}

1. Внукова Н.М. Економіко-правові аспекти пруденційного нагляду за страховою діяльністю. Право та інновації: наук. практ. журн. / редкол.: Ю.С. Атаманова та ін. Х.: Право. 2015. № 3 (11).

2. Временко Л. В., Корват О. В. Напрями вдосконалення системи пруденційного нагляду за страховою діяльністю. Грудневі читання «Міжнародні фінансові та страхові ринки в нових економічних умовах»: зб. тез доп. VI Міжнар. наук.-практ. конф. Вип. 6: у 2 т. (м. Київ, 16 грудня 2010 р.). К. : КНУ ім.Т. Шевченка. 2010. T. 1 .

3. Концепція запровадження пруденційного нагляду за небанківськими фінансовими установами в Державній комісії з регулювання ринків фінансових послуг України : затв. розпорядженням Держфінпослуг України від 15.07.10 p. № 585. URL: http://www.dfp.gov.ua/fileadmin/downloads/uoazk (дата звернення: 14.04.2018).

4. Положення про Національну комісію, що здійснює державне регулювання у сфері ринків фінансових послуг та з урахуванням наказу Національного агентства України з питань державної служби від 20.12.2016 № 277. URL: http://zakon3.rada.gov.ua/laws/show/1070/2011 (дата звернення: 11.04.2018).

5. Про Національну комісію, що здійснює державне регулювання у сфері ринків фінансових послуг України: Указ Президента України від 23.11.2011 № 1070. URL: http://zakon2.rada.gov.ua/laws/show/1070/2011 (дата звернення: 12.04.2018).

6. Про фінансові послуги та державне регулювання ринків фінансових послуг: Закон України. URL: http:// zakon3.rada.gov.ua/laws/show/2664-14 (дата звернення: 12.04.2018).

7. Sprawozdanie z działalności komisji nadzoru finansowego w 2016 roku, (Публічний звіт про діяльність Комісії фінансового нагляду Польщі за 2016 рік) URL: https://www.knf.gov.pl/knf/pl/komponenty/img/Sprawozdanie (дата звернення: 12.04.2018). 
8. Sprawozdanie z działalności komisji nadzoru finansowego w 2017 roku (Публічний звіт про діяльність Комісії фінансового нагляду Польщі за 2017 рік). URL: https://www.knf.gov.pl/knf/pl/komponenty/ img/PRZYJ\%C4\%98TY_NA_POSIEDZENIU_10_04_2018_Sprawozdanie_2017_61508.pdf. (дата звернення: 10.04.2018).

9. Публічний звіт про діяльність Національної комісії, що здійснює державне регулювання у сфері ринків фінансових послуг, за 2014 рік. URL: https://nfp.gov.ua/content/rzviti-nackomfinposlug.html. (дата звернення: 07.04.2018).

10. Публічний звіт про діяльність Національної комісії, що здійснює державне регулювання у сфері ринків фінансових послуг, за 2015 рік. URL: https://nfp.gov.ua/content/rzviti-nackomfinposlug.html. (дата звернення: 08.04.2018).

11. Публічний звіт про діяльність Національної комісії, що здійснює державне регулювання у сфері ринків фінансових послуг, за 2016 рік. URL: https://nfp.gov.ua/content/rzviti-nackomfinposlug.html. (дата звернення: 09.04.2018).

12. Публічний звіт про діяльність Національної комісії, що здійснює державне регулювання у сфері ринків фінансових послуг, за 2017 рік. URL: https://www.nfp.gov.ua/files/ZVIT2017/\%D0\%97\%D0\%92\%D0\%86\%D0\% A2 2017.p (дата звернення: 09.04.2018).

13. Kraś I., Organizacja nadzoru nad systemem finansowy w Polsce. URL: http://ssp.amu.edu.pl/wp-content/ uploads/2017/10/ssp-2017-1-09.pdf. (дата звернення: 07.04.2018).

14. Nadolska A., Komisja Nadzoru Finansowego w nowej instytucjonalnej architekturze europejskiego nadzoru finansowego, Wolters Kluwer, Warszawa 2014.

15. Monkiewicz J., Monkiewicz M., Tendencje rozwoju ochrony konsumentów na rynku ubezpieczeniowym. Nowe koncepcje i rozwiązania. URL: https://rf.gov.pl/pdf/JanMonkiewiczMarekMonkiewicz_Konsument_ubezpieczony_ ost.pdf. (дата звернення: 09.04.2018).

16. Ustawa o nadzorze nad rynkiem finansowym z dnia 21 lipca 2006, Dz.U. 2018, poz. 621, (Закон про нагляд нагляд за фінансовим ринком від 21 липня 2006). URL: http://prawo. sejm.gov.pl/isap.nsf/download.xsp/ WDU20180000621(дата звернення: 11.04.2018). 